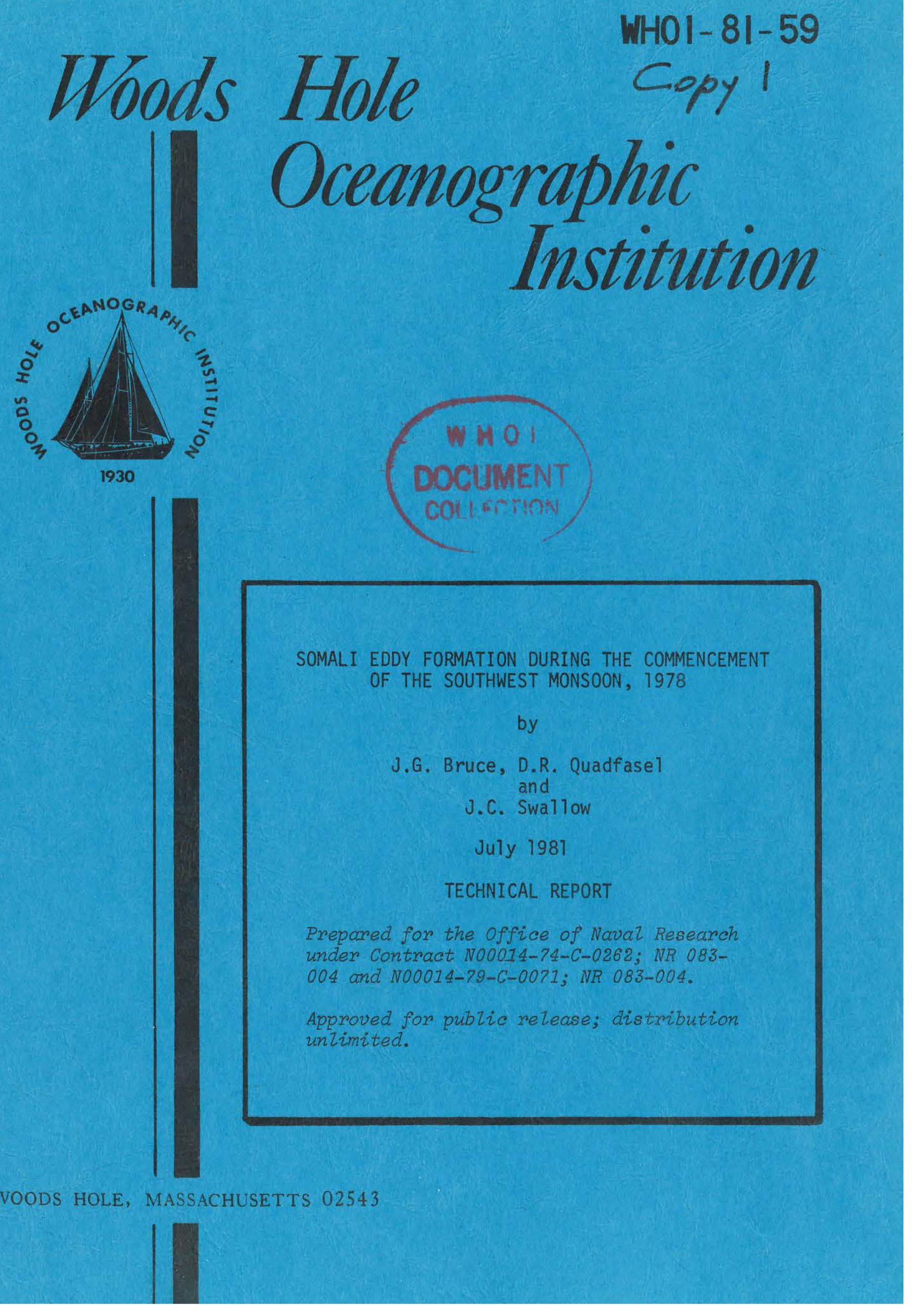




$$
\text { WHOI }-81-59
$$

\title{
SOMALI EDDY FORMATION DURING THE COMMENCEMENT \\ OF THE SOUTHWEST MONSOON, 1978
}

\author{
J.G. Bruce, D.R. Quadfasel \\ and \\ J.C. Swallow
}

WOODS HOLE OCEANOGRAPHIC INSTITUTION

Woods Hole, Massachusetts 02543

July 1981

TECHNICAL REPORT

Prepared for the Office of Naval Research under Contracts N00014-74-C-0262; 'NR 083-004 and N00014-79-C-0071; NR 083004 .

Reproduction in whole or in part is permitted for any purpose of the United States Govermment. In citing this report in a bibliography, the reference given should be to: Joumal of Geophysical Research 85(C11): 6654-6660 (November 20, 1980).

Approved for public release; distribution unlimited.

Approved for distribution: Valentine Worthington, Chairman Department of Physical Oceanography 


\title{
Somali Eddy Formation During the Commencement of the Southwest Monsoon, 1978
}

\author{
J. G. BRUCE \\ Woods Hole Oceanographic Institution, Woods Hole, Massachusetts 02543 \\ D. R. Quadfasel and J. C. Swallow \\ Institute of Oceanographic Sciences, United Kingdom
}

\begin{abstract}
An early stage of the Somali eddy circulation was mapped in the period May 29 to June 13, 1978, using expendable bathythermograph data at closely spaced stations. By this time the SW monsoon had been blowing at $5^{\circ} \mathrm{N}$ for about 4 weeks and the large anticyclonic eddy in the northern Somali Basin was clearly discernible between $3^{\circ} \mathrm{N}$ and $10^{\circ} \mathrm{N}$. It is estimated that the offshore transport at this time was approximately half of that occurring during the period when the eddy reaches maximum size and strength during August and September. A smaller southern eddy was observed just offshore between the equator and $3^{\circ} \mathrm{N}$.
\end{abstract}

\section{INTRODUCTION}

Of the two monsoons regularly occurring each year in the northwest Indian Ocean, the southwest monsoon from April through September is much the stronger [Hellerman, 1967, 1968]. During this monsoon the Somali Current flows northeastward along the east African coast commencing by late April south of the equator [Leetmaa, 1972, 1973], progressing northward during May and reaching full strength during July and August [Swallow and Bruce, 1966]. In the vicinity of the Somali Basin at this time, large anticyclonic eddies are formed [Bruce, 1968]. The largest of these (diameter $400-600 \mathrm{~km}$ ) is termed the prime eddy [Bruce, 1979]. From existing evidence it appears to occur each year between approximately $4^{\circ} \mathrm{N}$ to $12^{\circ} \mathrm{N}$ and the Somali coast and $58^{\circ} \mathrm{E}$. An adjacent smaller eddy to the northeast off Socotra also seems to develop each year. During certain years an eddy forms adjacent to and to the south $\left(\sim 0^{\circ}\right.$ to $5^{\circ} \mathrm{N}$, Somali coast to $\left.53^{\circ} \mathrm{E}\right)$ of the prime eddy [Bruce, 1973, 1979]. The Somali Current is part of the eddy field of the prime and southern eddies. As the current turns offshore, its relatively fresh $(\sim 35.0-35.2 \%$ ) and cool water serves as a useful tracer for mapping the flow. In the region of upwelling on the left of the current as it diverges from the coast, near-surface temperatures range from roughly $12^{\circ}$ to $25^{\circ} \mathrm{C}$.

Previous surveys reported in the literature of the Somali Current and associated eddies have taken place during or slightly after the stage of maximum eddy strength during the southwest monsoon (August, September). The monsoon winds which drive the current system normally intensify from May through July and decline after this through September. A fortuitous set of near synoptic observations enables us in part to describe an earlier stage of the eddy development off the Somali and southeast Arabian coasts. Temperature sections were obtained during late May and early June 1978 from expendable bathythermographs (XBT's) by the Exxon tanker Al Duriyah and United Kingdom naval vessels HMS Hydra and HMS Hecate. The station positions were relatively closely spaced (15-30 n. mi. (25-50 km)) in order to study the smallscale features that occur in this region during the southwest

Copyright () 1980 by the American Geophysical Union. monsoon. The Al Duriyah observations were part of an on-going program for monitoring the characteristics of the eddy structure off the Somali and Arabian coasts from a time series

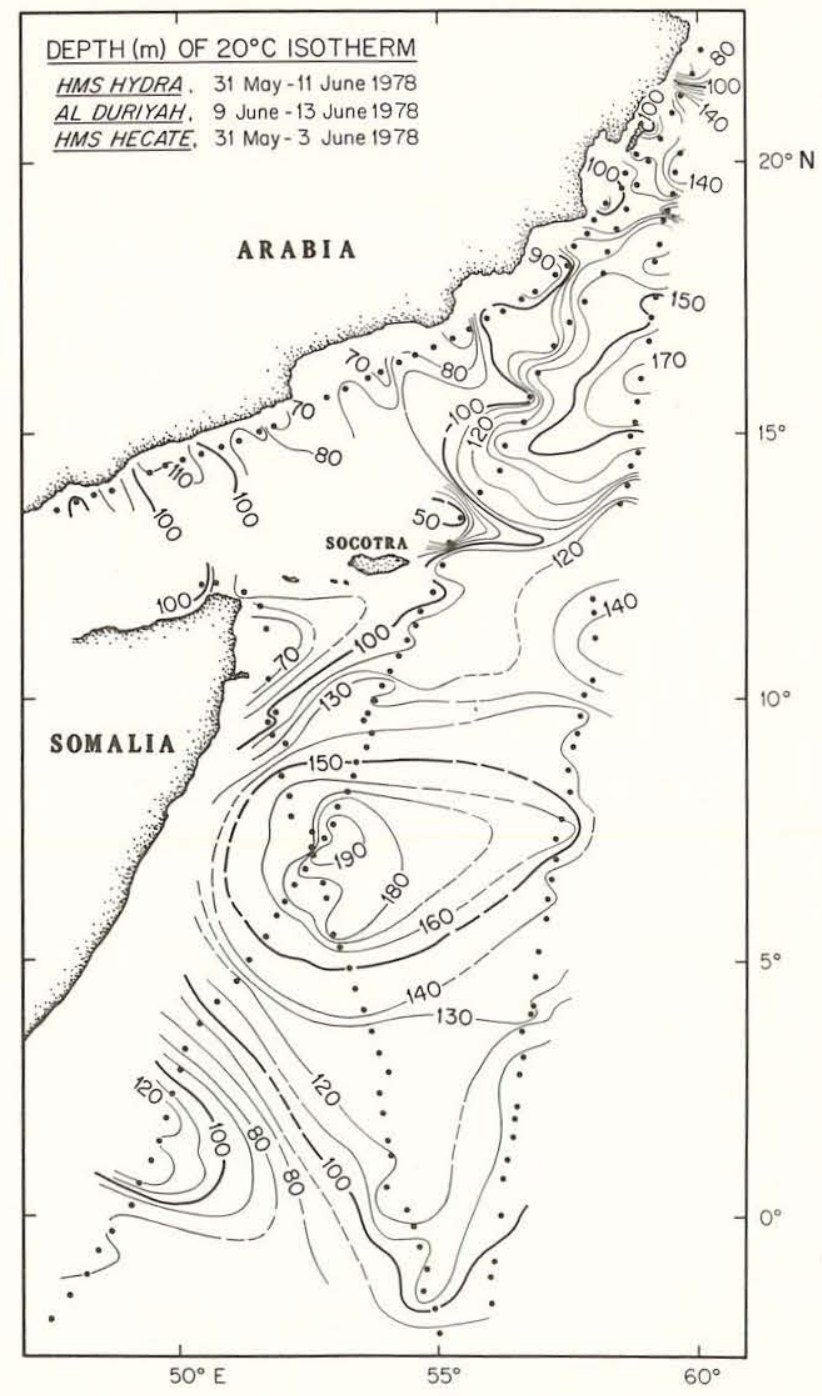

Fig. 1. Depth in meters of $20^{\circ} \mathrm{C}$ isotherm, May 29 to June 13,1978 . 


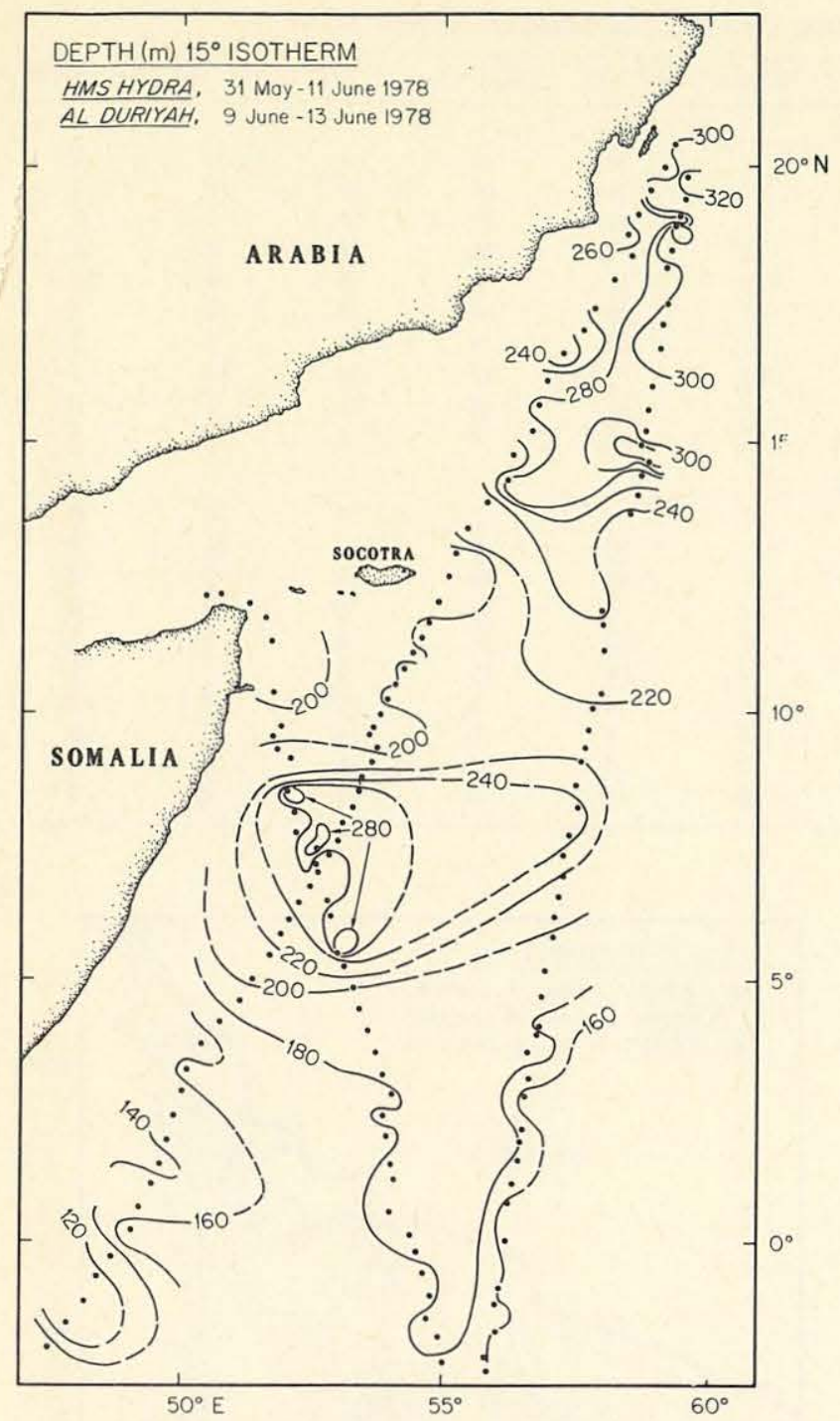

Fig. 2. Depth in meters of $15^{\circ} \mathrm{C}$ isotherm, May 29 to June 13,1978 .

of temperature sections made from Exxon tankers on approximately the same sea lane [Bruce, 1979].

\section{DATA}

The data consist of four XBT (Sippican Corp., T-4, $460 \mathrm{~m}$ probes) sections.

1. HMS Hydra, 55 stations from May $29,20^{\circ} 08^{\prime} \mathrm{N}$, $59^{\circ} 38^{\prime} \mathrm{E}$ to June $3,2^{\circ} 59^{\prime} \mathrm{S}, 55^{\circ} 45^{\prime} \mathrm{E}$.

2. HMS Hydra, 40 stations from June $8,3^{\circ} 39^{\prime} \mathrm{S}, 55^{\circ} 10^{\prime} \mathrm{E}$ to June $11,12^{\circ} 06^{\prime} \mathrm{N}, 50^{\circ} 30^{\prime} \mathrm{E}$.

3. Al Duriyah (Exxon tanker), 63 stations from June 7, $22^{\circ} 00^{\prime} \mathrm{N}, 60^{\circ} 05^{\prime} \mathrm{E}$ to June $13,2^{\circ} 00^{\prime} \mathrm{S}, 47^{\circ} 33^{\prime} \mathrm{E}$. Surface salinity, wind velocity, and ship's set by currents.

4. HMS Hecate, 35 stations from May $31,20^{\circ} 32^{\prime} \mathrm{N}$, $59^{\circ} 10^{\prime} \mathrm{E}$ to June $3,13^{\circ} 18^{\prime} \mathrm{N}, 46^{\circ} 52^{\prime} \mathrm{E}$.

Further data discussed here but not used in the horizontal maps were obtained earlier by Esso Osaka May 19 to 21, 1978, and consist of 24 stations along the tanker sea lane which are located approximately 20-25 mi. (35-45 km) east of those of Al Duriyah. Additional data obtained when the eddy was further developed are presented from an Esso Atlantic July 6-8, 1978 , section, 31 stations. Maps of the mean depth of the $20^{\circ} \mathrm{C}$ isotherm for May and June, used data from the following sources: NODC, Hydrographic Office of the Navy (United Kingdom), EAMFRO (Zanzibar), WHOI (Atlantis II, 1976), La Curieuse (H. Stommel, WHOI), Hydra (this paper), and Exxon tankers (J. Bruce, WHOI). The coastal wind observations were provided by the Somali Meteorological Service.

\section{INTERPRETATION OF SYNOPTIC MAPS}

In the Somali Basin the $20^{\circ} \mathrm{C}$ isotherm reaches its greatest depth of over $190 \mathrm{~m}$ in the region around $7^{\circ} \mathrm{N}, 53^{\circ} \mathrm{W}$ (Figure 1) about which a closed circulation is indicated by the depth contours between 150 and $190 \mathrm{~m}$. The strongest gradients extend from this region northward to $11^{\circ} \mathrm{N}$ and to the south to about $4^{\circ} \mathrm{N}$. The circulation as contoured turns offshore at approximately $8^{\circ} \mathrm{N}-9^{\circ} \mathrm{N}$ across the Hydra track, proceeds toward the east, and then turns southward between $54^{\circ} \mathrm{E}-57^{\circ} \mathrm{E}$. A return flow toward the west is indicated between $7^{\circ} \mathrm{N}$ and $0^{\circ}$ east of $52^{\circ} \mathrm{E}$. The isotherm shoals to less than $70 \mathrm{~m}$ just off northeastern Somalia. It should be noted that the stations obtained in the center of the circulation all were obtained within a 2-day period (June 10-12) and it is expected that time aliasing would be relatively small here. The circulation appears to be that of the prime eddy [Bruce, 1979] in its early stage of development during the $\mathrm{SW}$ monsoon. There is also a deepening of the isotherm around $2^{\circ} \mathrm{N}$ with depths exceeding $120 \mathrm{~m}$. An offshore flow is suggested in the region $3^{\circ} \mathrm{N}-4^{\circ} \mathrm{N}$.

Another large-scale feature appears between $14^{\circ} \mathrm{N}$ and $18^{\circ} \mathrm{N}$ off the Arabian coast. Close to the coast (HMS Hecate) considerable variation in isotherm depth suggests the presence of several small-scale features.

Of these three depressions in the depth of the $20^{\circ} \mathrm{C}$ isotherm, only the one at $7^{\circ} \mathrm{N}$ (prime eddy) is clearly discernible in the map of the depth of the $15^{\circ} \mathrm{C}$ isotherm (Figure 2). Evidence of isotherm deepening appears in the three tracks, with

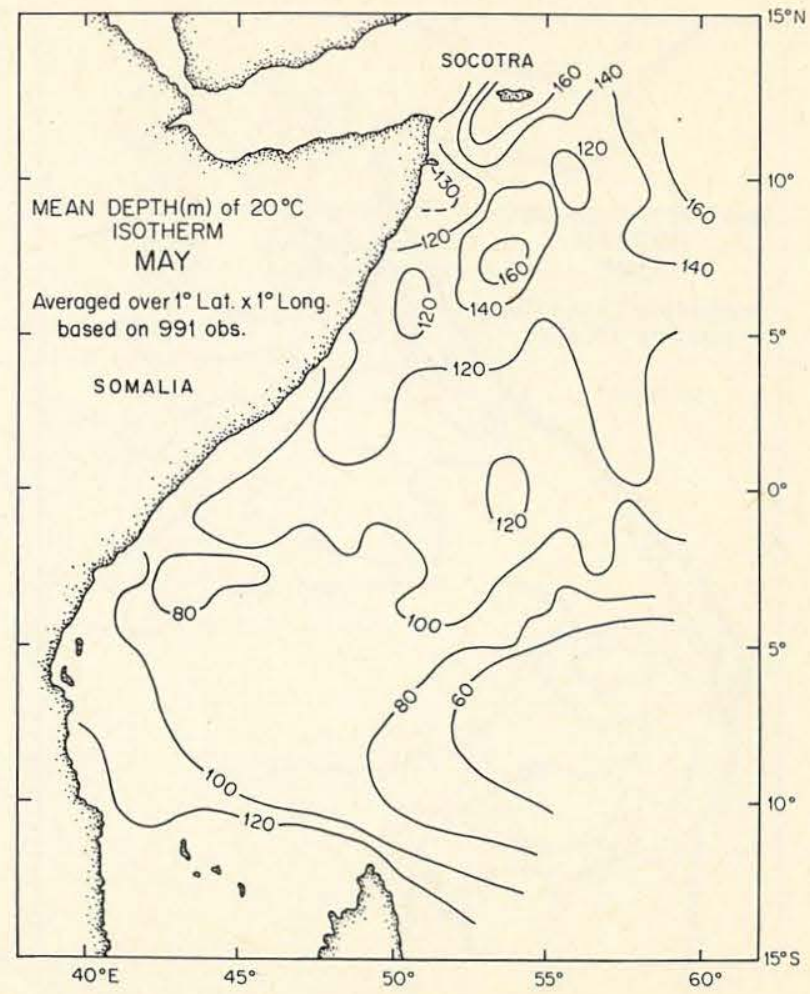

Fig. 3. Mean depth in meters of $20^{\circ} \mathrm{C}$ isotherm for May (see text for data sources). 
TABLE 1. Number of Observations in Somali Basin Used for Construction of Figures 3 and 4

\begin{tabular}{|c|c|c|c|c|c|c|c|c|c|c|c|}
\hline & $38^{\circ}-40^{\circ} \mathrm{E}$ & $40^{\circ}-42^{\circ}$ & $42^{\circ}-44^{\circ}$ & $44^{\circ}-46^{\circ}$ & $46^{\circ}-48^{\circ}$ & $48^{\circ}-50^{\circ}$ & $50^{\circ}-52^{\circ}$ & $52^{\circ}-54^{\circ}$ & $54^{\circ}-56^{\circ}$ & $56^{\circ}-58^{\circ}$ & $58^{\circ}-60^{\circ} \mathrm{E}$ \\
\hline \multicolumn{12}{|c|}{ May } \\
\hline $12^{\circ} \mathrm{N}-14^{\circ} \mathrm{N}$ & & & & & & & 6 & 1 & 9 & 3 & 0 \\
\hline $10^{\circ} \mathrm{N}-12^{\circ} \mathrm{N}$ & & & & & & & 6 & 14 & 30 & 19 & 1 \\
\hline $8^{\circ} \mathrm{N}-10^{\circ} \mathrm{N}$ & & & & & & & 12 & 24 & 11 & 3 & 9 \\
\hline $6^{\circ} \mathrm{N}-8^{\circ} \mathrm{N}$ & & & & & & 2 & 7 & 26 & 4 & 4 & 8 \\
\hline $4^{\circ} \mathrm{N}-6^{\circ} \mathrm{N}$ & & & & & & 9 & 22 & 9 & 4 & 4 & 11 \\
\hline $2^{\circ} \mathrm{N}-4^{\circ} \mathrm{N}$ & & & & & 11 & 2 & 20 & 14 & 5 & 2 & 1 \\
\hline $0^{\circ} \mathrm{N}-2^{\circ} \mathrm{N}$ & & & & 15 & 3 & 11 & 10 & 5 & 37 & 1 & 1 \\
\hline $2^{\circ} \mathrm{S}-0^{\circ}$ & & 1 & 12 & 7 & 12 & 35 & 7 & 12 & 34 & 13 & 1 \\
\hline $4^{\circ} \mathrm{S}-2^{\circ} \mathrm{S}$ & & 26 & 19 & 11 & 3 & 4 & 11 & 9 & 23 & 1 & 0 \\
\hline $6^{\circ} \mathrm{S}-4^{\circ} \mathrm{S}$ & 4 & 20 & 16 & 11 & 10 & 7 & 11 & 9 & 1 & 2 & 4 \\
\hline \multicolumn{12}{|c|}{ June } \\
\hline $12^{\circ} \mathrm{N}-14^{\circ} \mathrm{N}$ & & & & & & & & 2 & 7 & 0 & 0 \\
\hline $10^{\circ} \mathrm{N}-12^{\circ} \mathrm{N}$ & & & & & & & 10 & 9 & 15 & 16 & 8 \\
\hline $8^{\circ} \mathrm{N}-10^{\circ} \mathrm{N}$ & & & & & & & 18 & 36 & 13 & 5 & 2 \\
\hline $6^{\circ} \mathrm{N}-8^{\circ} \mathrm{N}$ & & & & & & 4 & 6 & 35 & 0 & 7 & 0 \\
\hline $4^{\circ} \mathrm{N}-6^{\circ} \mathrm{N}$ & & & & & & 7 & 22 & 18 & 0 & 6 & 2 \\
\hline $2^{\circ} \mathrm{N}-4^{\circ} \mathrm{N}$ & & & & & 5 & 4 & 14 & 15 & 2 & 7 & 11 \\
\hline $0^{\circ}-2^{\circ} \mathrm{N}$ & & & & 8 & 2 & 15 & 4 & 3 & 10 & 10 & 32 \\
\hline $2^{\circ} \mathrm{S}-0^{\circ}$ & & & 7 & 4 & 7 & 18 & 1 & 0 & 16 & 3 & 25 \\
\hline $4^{\circ} \mathrm{S}-2^{\circ} \mathrm{S}$ & & 9 & 10 & 6 & 2 & 0 & 0 & 0 & 16 & 10 & 20 \\
\hline $6^{\circ} \mathrm{S}-4^{\circ} \mathrm{S}$ & 2 & 9 & 6 & 4 & 2 & 0 & 0 & 0 & 0 & 4 & 7 \\
\hline
\end{tabular}

the greatest depths being $>280 \mathrm{~m}$. The southern feature apparently is not sufficiently deep to produce a recognizable feature.

There is evidence of the formation of the prime eddy in the mean maps (Figures 3 and 4, Table 1). During May a region in which the isotherm has commenced to deepen to over $140 \mathrm{~m}$ is centered about $7^{\circ} \mathrm{N}, 54^{\circ} \mathrm{E}$, however, the only shoaling of the isotherm is along the Somali coast between the equator and about $4^{\circ} \mathrm{N}$. By June the deepening has increased over a larger

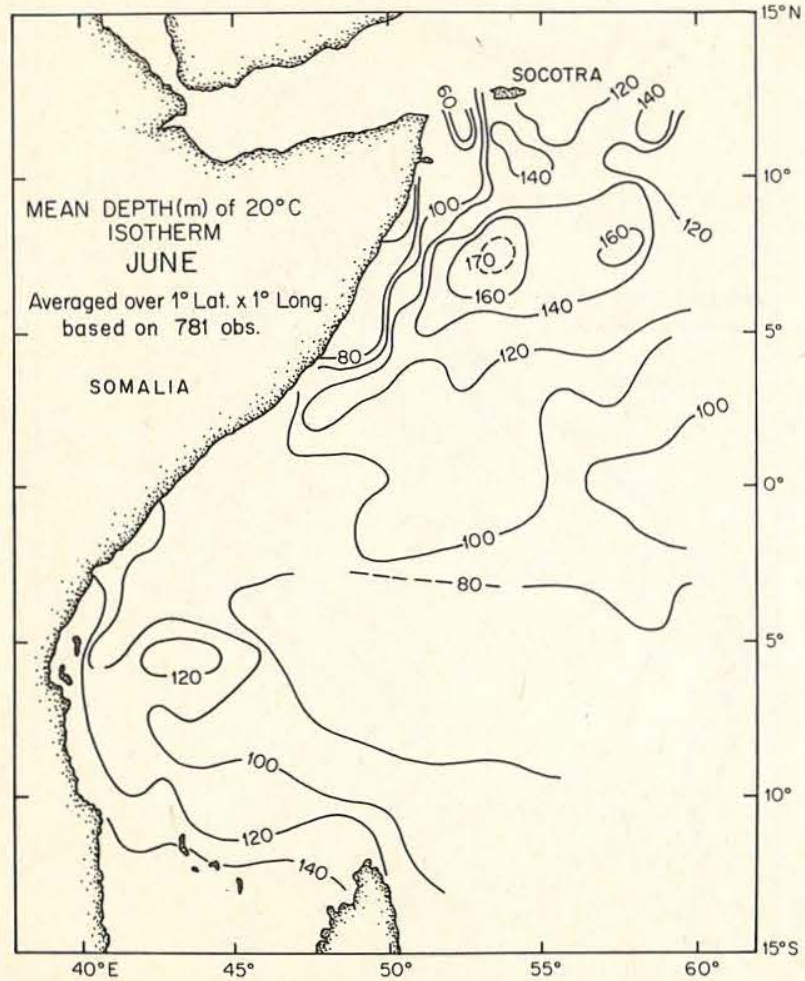

Fig. 4. Mean depth in meters of $20^{\circ} \mathrm{C}$ isotherm for June (see text for data sources)

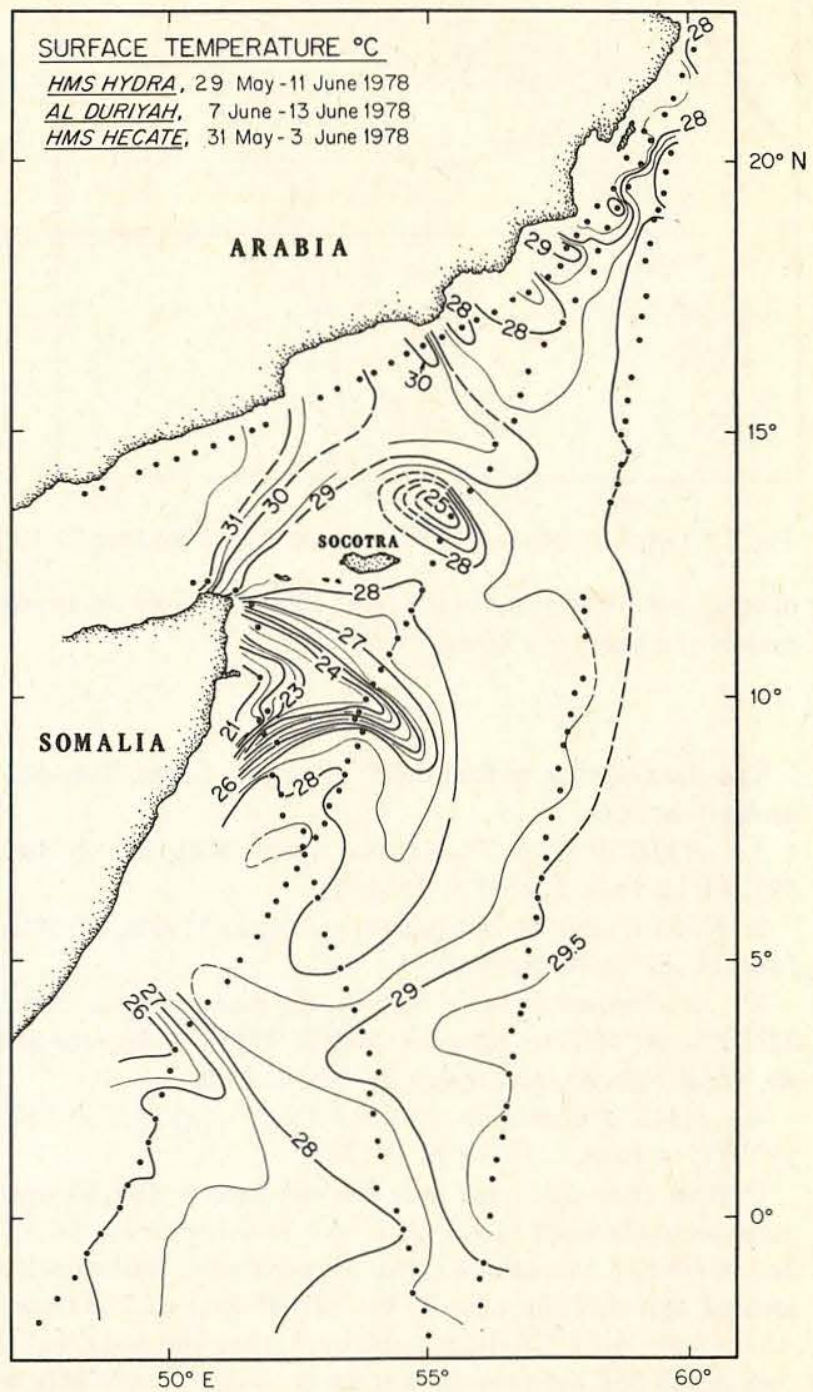

Fig. 5. Surface temperature, in degrees Celsius, May 29 to June 13, 1978. 


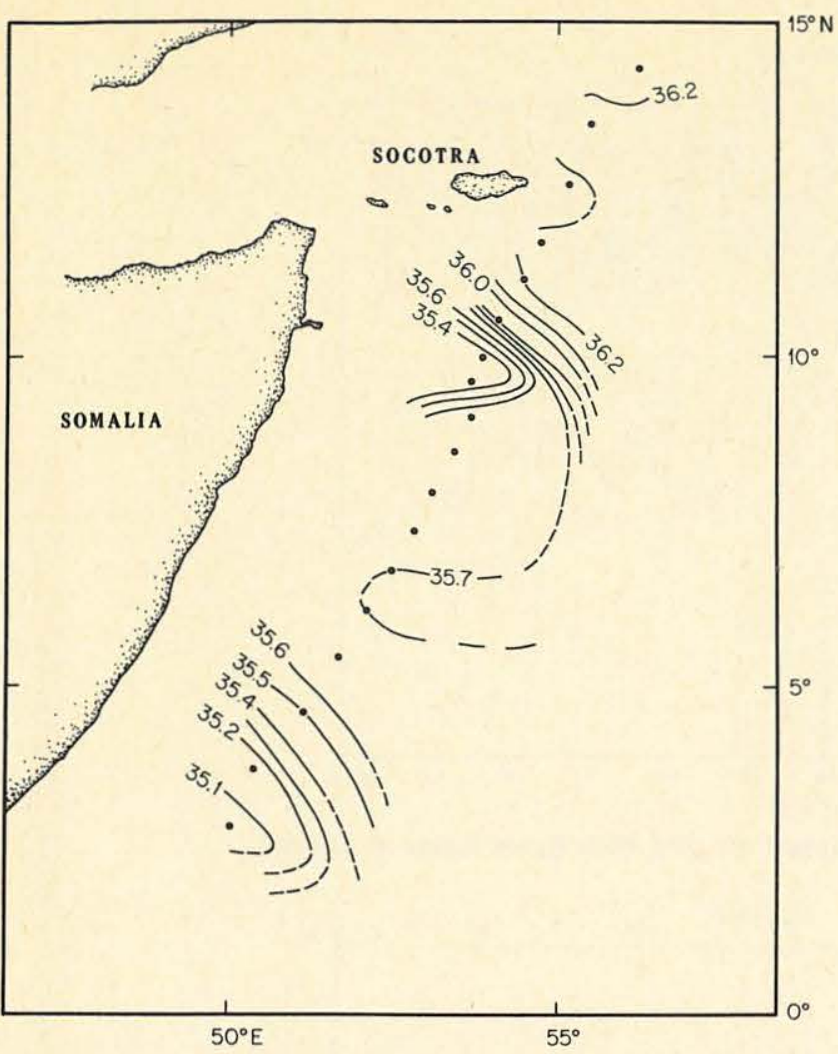

Fig. 6. Surface salinity, \%, June 9-12, 1978, from Exxon tanker $\mathrm{Al}$ Duriyah.

area as has the shoaling along the coast north of $5^{\circ} \mathrm{N}$ to $<80$ $\mathrm{m}$. However, tanker sections for May and June from previous years show that there is no significant deepening of the $15^{\circ} \mathrm{C}$ isotherm in this region. Average depths are around $220 \mathrm{~m}$ and no uplifting of the deep isotherms toward $10^{\circ}-12^{\circ} \mathrm{N}$ was observed. Therefore in 1978 there seems to be an unusually deep development of the eddy at this stage of the SW monsoon.

The relatively cool and fresh characteristics of the Somali Current are evident at the height of the southwest monsoon [Warren et al., 1966; Bruce, 1968] and can be useful in preparing maps to help delineate patterns of circulation. Maps of surface temperature and salinity drawn from our May 29 to June 13, 1978, observations (Figures 5 and 6) show that coastal upwelling around $10^{\circ} \mathrm{N}$ has already developed strongly with horizontal gradients of about $6^{\circ} \mathrm{C}$ over a degree of latitude and minimum temperatures of $<21^{\circ} \mathrm{C}$. Past surveys during August have observed water in this region with temperatures of $<14^{\circ} \mathrm{C}$ [Bruce, 1974]. As during the period of maximum development of the eddy, the cold and fresh $(<35.4 \%$ ) water is advected offshore to the east along the northern boundary of the anticyclonic eddy. To the south, the smaller circulation also is advecting the coastal water to the southeast.

The slope of the isotherms and horizontal thermal gradients along the sides of the prime eddy appear between $3^{\circ} \mathrm{N}$ and $10^{\circ} \mathrm{N}$ in both $\mathrm{Hydra}$ and $\mathrm{Al}$ Duriyah vertical sections (Figures 7 and 8). At the center of the eddy the gradients which appear to be associated with the eddy are present to about $300-\mathrm{m}$ depth in these sections. The Hydra section, when compared with an August, 1964 Discovery section [Swallow and Bruce, 1966] which is on a similar track, shows that the deeper isotherms $\left(15^{\circ}-20^{\circ} \mathrm{C}\right)$ have not yet attained the pronounced slope found later during the monsoon, however, those $>20^{\circ} \mathrm{C}$ are rather similar. The southern feature is relatively shallow appearing to extend from the surface to about $120-\mathrm{m}$ depth at $2^{\circ} \mathrm{N}$.

\section{Time Evolution of THE PRIME EdDY}

The observations along essentially the same tanker sea lane ( $\pm 20 \mathrm{n}$. mi. $( \pm 35 \mathrm{~km})$ ) both before (May 19-21, 1978, Esso Os$a k a$ ) and after (July 6-8, 1978, Esso Atlantic) those of Al Duriyah may be used to follow the development of the eddy between $4^{\circ} \mathrm{N}$ and $12^{\circ} \mathrm{N}$. The temperature sections of these two ships are shown by Bruce [1979]. We have estimated dynamic heights and geostrophic volume transports for the XBT stations along the three tanker and Hydra sections (Figure 9 and Table 2). A mean temperature-salinity (TS) distribution was assumed based on data from previous surveys in the western equatorial and Somali Basin region [Bruce, 1979]. The major changes in dynamic height during the southwest monsoon are a function of temperature [Bruce, 1979]. Errors incurred by assuming a unique TS relationship for all stations are unlikely to exceed \pm 0.03 dynamic meters (dy. $\mathrm{m}$ ).

There is an increase of the dynamic height in the central region of the eddy from $1.23 \mathrm{dy}$. m (Esso Osaka) to $1.29 \mathrm{dy}$. m (Al Duriyah, Hydra) in 3 weeks then to 1.36 dy. m (Esso Atlantic) after another 3-week interval. Also the trough $\left(10^{\circ} \mathrm{N}-\right.$ $11^{\circ} \mathrm{N}$ ) on the northern edge of the eddy becomes correspondingly lower in value.

Offshore geostrophic volume transport (Table 2) across the tanker lane increases from 14.8 to $33.3 \times 10^{6} \mathrm{~m}^{3} \mathrm{~s}^{-1}$ during this period, whereas maximum values occurring later during the fully developed circulation may reach $42 \times 10^{6} \mathrm{~m}^{3} \mathrm{~s}^{-1}$ [Bruce, 1979]. The offshore transport through the Hydra section is $7.5 \times 10^{6} \mathrm{~m}^{3} \mathrm{~s}^{-1}$ greater than that of the approximately contemporaneous Al Duriyah section and suggests a flow toward the north between Socotra and Cape Guardafui. The return flow to the west across the tanker lane in each case is

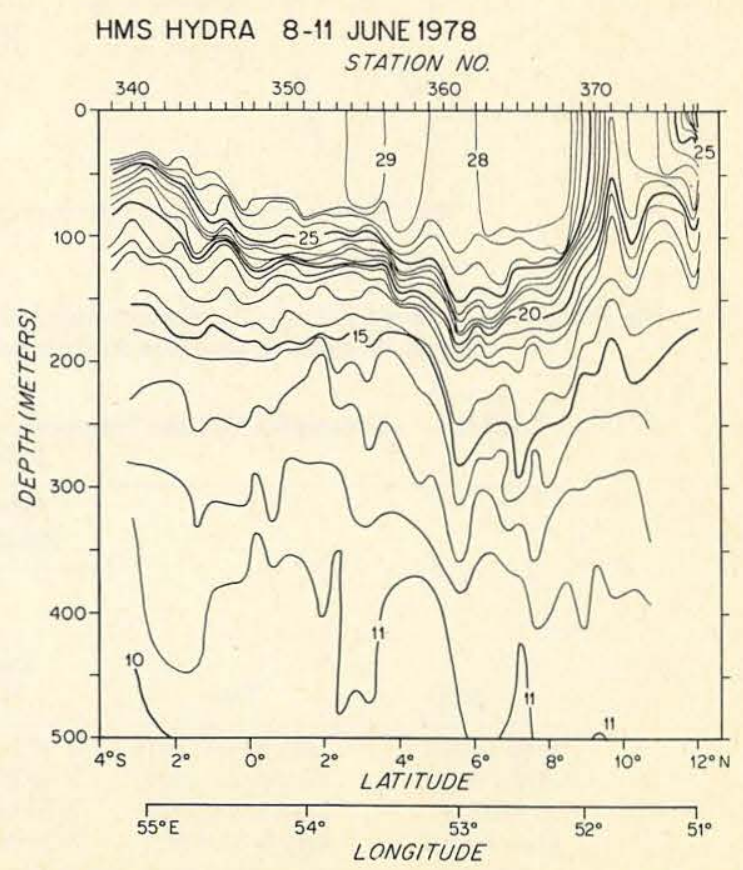

Fig. 7. Temperature section, in degrees Celsius, June 8-11, 1978, from HMS Hydra. 


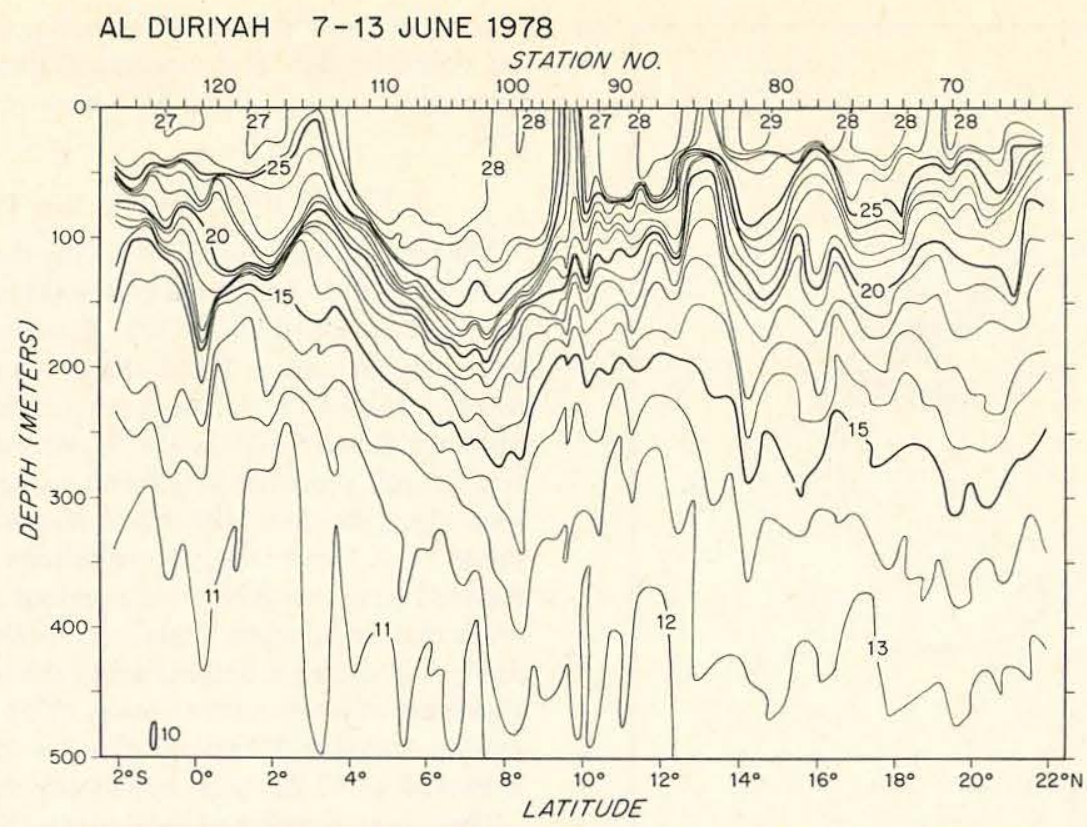

Fig. 8. Temperature section, in degrees Celsius, June 7-13, 1978, from Exxon tanker Al Duriyah.

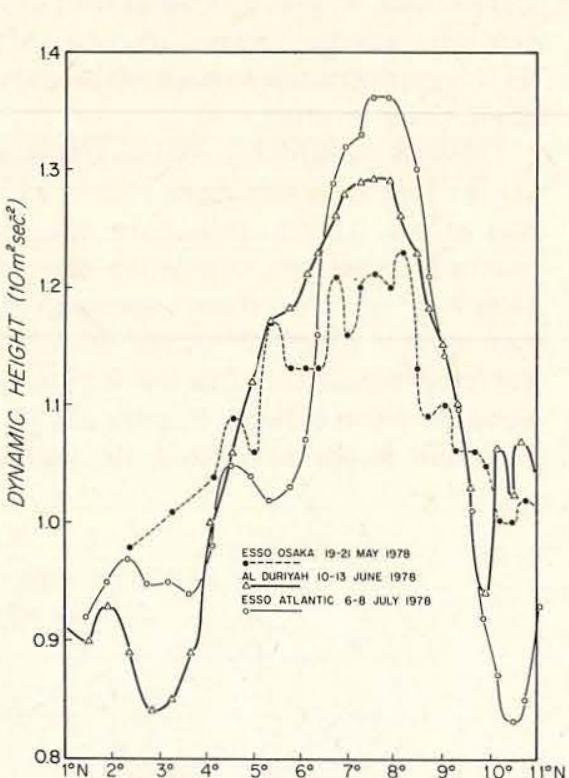

LATITUDE

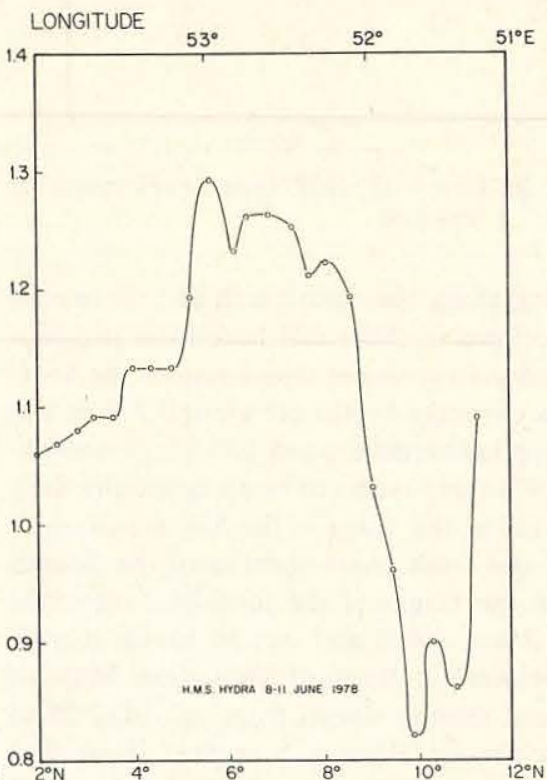

LATITUDE

Fig. 9. Dynamic height $\left(10 \mathrm{~m}^{2} \mathrm{~s}^{-2}\right)$ of sea surface relative to $400 \mathrm{dbar}$ along tanker sea lane, $1^{\circ} \mathrm{N}-11^{\circ} \mathrm{N}$ (left) for Esso Osaka, Al Duriyah, and Esso Atlantic and (right) for HMS Hydra (see Figure 1 for tracks).

TABLE 2. Geostrophic Volume Transport, 0-400 dbar, Relative to 400 dbar of Prime Eddy in Somali $\operatorname{Basin}\left(4^{\circ} \mathrm{N}-12^{\circ} \mathrm{N}\right)$

\begin{tabular}{|c|c|c|c|c|c|c|}
\hline \multirow[b]{2}{*}{ Ship } & \multirow[b]{2}{*}{ Date } & \multicolumn{2}{|c|}{$\begin{array}{l}\text { Offshore Transport, } \\
\text { Northern Part of Eddy }\end{array}$} & \multirow[b]{2}{*}{$\begin{array}{c}\text { Azi- } \\
\text { muth } \\
\text { of } \\
\text { Sec- } \\
\text { tion, } \\
\text { deg }\end{array}$} & \multicolumn{2}{|c|}{$\begin{array}{l}\text { Onshore Transport, } \\
\text { Southern Part of Eddy }\end{array}$} \\
\hline & & $\begin{array}{l}\text { Latitude } \\
\text { Range }\end{array}$ & $\begin{array}{c}\text { Volume } \\
\text { Trans- } \\
\text { port, } \\
\times 10^{6} \\
\mathrm{~m}^{3} \mathrm{~s}^{-1} \\
\end{array}$ & & $\begin{array}{l}\text { Latitude } \\
\text { Range }\end{array}$ & $\begin{array}{c}\text { Volume } \\
\text { Trans- } \\
\text { port, } \\
\times 10^{6} \\
\mathrm{~m}^{3} \mathrm{~s}^{-1} \\
\end{array}$ \\
\hline Esso Osaka & May $19-21,1978$ & $8^{\circ} 10^{\prime} \mathrm{N}-11^{\circ} 15^{\prime} \mathrm{N}$ & 15 & 030 & $4^{\circ} 10^{\prime} \mathrm{N}-8^{\circ} 10^{\prime} \mathrm{N}$ & 23 \\
\hline HMS Hydra & June 8-11, 1978 & $5^{\circ} 40^{\prime} \mathrm{N}-9^{\circ} 50^{\prime} \mathrm{N}$ & 27 & 345 & $4^{\circ} 00^{\prime} \mathrm{N}-5^{\circ} 40^{\prime} \mathrm{N}$ & 28 \\
\hline Al Duriyah & June 9-13, 1978 & $7^{\circ} 50^{\prime} \mathrm{N}-9^{\circ} 50^{\prime} \mathrm{N}$ & 19 & 030 & $4^{\circ} 10^{\prime} \mathrm{N}-7^{\circ} 50^{\prime} \mathrm{N}$ & 39 \\
\hline Esso Atlantic & July $6-8,1978$ & $7^{\circ} 30^{\prime} \mathrm{N}-10^{\circ} 30^{\prime} \mathrm{N}$ & 33 & 030 & $4^{\circ} 10^{\prime} \mathrm{N}-7^{\circ} 30^{\prime} \mathrm{N}$ & 45 \\
\hline
\end{tabular}

Data from XBT stations with same TS distribution assumed for each station (TS are mean values determined from past surveys). 


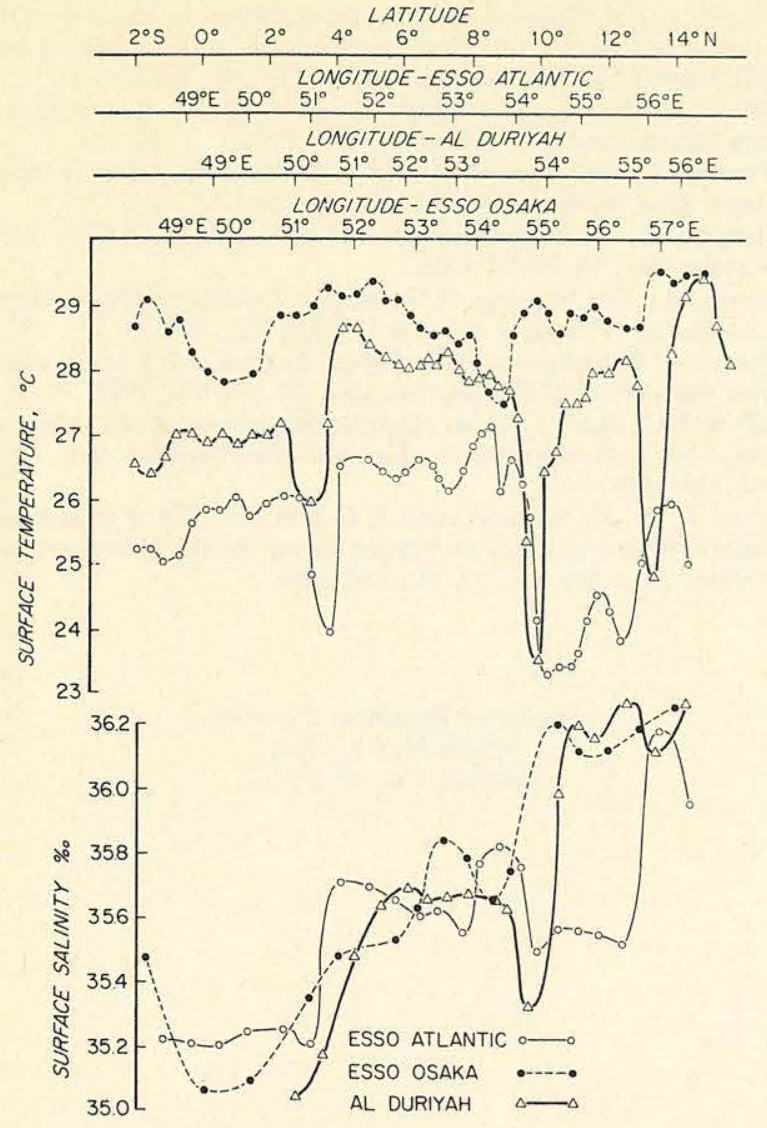

Fig. 10. Surface temperature, degrees Celsius (top), and surface salinity, \%o (bottom), along tanker sea lane $\left(2^{\circ} \mathrm{S}-15^{\circ} \mathrm{N}\right)$ for Esso Osaka, May 18-22, 1978; Al Duriyah, June 9-13, 1978; and Esso Atlantic, July 6-9, 1978.

larger than the offshore value and may in part be due to additional water advecting into the eddy from the southeast.

Surface temperature and surface salinity along the tanker sections from $2^{\circ} \mathrm{S}$ to $15^{\circ} \mathrm{N}$ for Esso Osaka, Al Duriyah, and Esso Atlantic further serve to follow the development of the Somali Basin eddies (Figure 10). The increase in the signal of the relatively cold, fresh surface water originating in the South Equatorial Current and in the upwelling regions which is advected offshore along the northern edge of both eddies as the southwest monsoon progresses is apparent at $10^{\circ} \mathrm{N}$ and $2^{\circ} \mathrm{N}-4^{\circ} \mathrm{N}$. In May the salinity increases roughly linearly toward the north while in the later stages the profiles have sharp gradients at the eddy boundaries. The increased horizontal mixing within the eddies tends to produce plateaus in the surface salinity profiles, e.g., Al Duriyah, $5^{\circ} \mathrm{N}-9^{\circ} \mathrm{N}$. An overall decrease in the surface temperature with time also may be seen.

\section{WIND OBSERVATIONS}

Observations of surface winds along the tanker lane and at three coastal stations in Somalia show the reversal of the wind field over the western Indian Ocean in 1978. In Figure 11 wind vectors are plotted for four different time periods between March and June.

At the end of March the general airflow was still northeasterly. Two weeks later in April the monsoon reversal started and winds south of $5^{\circ} \mathrm{N}$ became southeasterly. Speeds, however, were still less than $5 \mathrm{~m} \mathrm{~s}^{-1}$. The southwest monsoon wind field developed along the Somali coast during April. The actual onset defined by a change in direction of more than $90^{\circ}$ and reaching $50 \%$ of wind speed of the fully developed southwest monsoon [Fieux and Stommel, 1977] progressed northward. The time series of wind observations from the coastal stations indicate an onset at Chisimaio on March 27 and at Obbia on May 1. By mid-May the reversal was completed and wind speeds reached $16 \mathrm{~m} \mathrm{~s}^{-1}$ at $10^{\circ} \mathrm{N}$ and increased to more than $23 \mathrm{~m} \mathrm{~s}^{-1}$ in early June. By that time the pattern of airflow was similar to that observed in earlier investigations [e.g., Findlater, 1971].

At around $2^{\circ} \mathrm{N}-3^{\circ} \mathrm{N}$ the wind field appears to have a discontinuity after mid-May. The wind developed a strong offshore component and during this initial phase of the southwest monsoon the wind speeds increased from 3 to $10 \mathrm{~m} \mathrm{~s}^{-1}$. This aspect of the wind field might account in part for the development of the offshore current in this region.

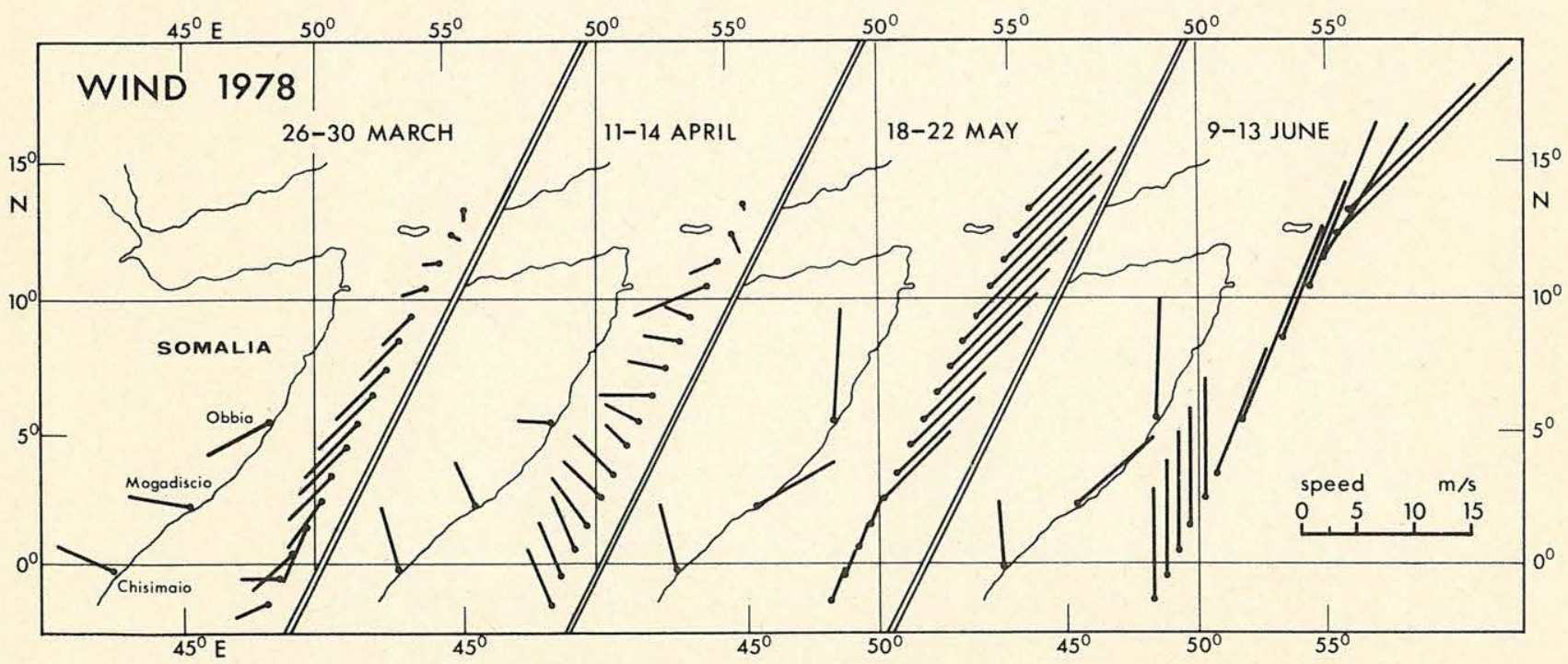

Fig. 11. Surface winds during commencement of southwest monsoon 1978 along tanker sea lane and three shore stations. Note that stick vectors are pointing in the direction toward which wind is blowing. 
Acknowledgments. The authors are indebted to the hydrographer of the Navy (U.K.) for making available the XBT data from the British surveying ships HMS Hydra and HMS Hecate. Special thanks are due to the Exxon Corporation for their considerable help in allowing us to use their tankers for XBT measurements and to the University of Cape Town oceanographic department staff: E. S. W. Simpson and observers L. Wolhuter and M. Broad for their large effort in the data acquisition. Wind data from Somali coastal stations were kindly supplied us by the Meteorological Service of the Somali Democratic Republic. J. G. B. was supported by the Office of Naval Research under contract N00014-74-C-0262, NR 083-004 and N00014-79-C-0071, NR 083-004. D. R. Q was supported by the GRAFOG of University of Kiel (Federal Republic of Germany). Woods Hole Oceanographic Institution contribution 4496 .

\section{REFERENCES}

Bruce, J. G., Comparison of near surface dynamic topography during the two monsoons in the western Indian Ocean, Deep Sea Res., 15(6), 665-677, 1968.

Bruce, J. G., Large scale variations of the Somali Current during the southwest monsoon, 1970, Deep Sea Res., 20(9), 837-846, 1973.

Bruce, J. G., Upwelling off the Somali and Arabian coasts, J. Mar. Res., 32(3), 419-423, 1974.

Bruce, J. G., Eddies off the Somali coast during the southwest monsoon, J. Geophys. Res., 84, 7742-7748, 1979.
Fieux, M., and H. Stommel, Onset of the southwest monsoon over the Arabian Sea from marine reports of surface winds: Structure and variability, Mon. Weather Rev., 105(2), 231-236, 1977.

Findlater, J., Mean monthly airflow at low levels over the western Indian Ocean, Geophys. Mem., 115, 1-53, 1971.

Hellerman, S., An updated estimate of the wind stress on the world ocean, Mon. Weather Rev., 95, 607-626, 1967.

Hellerman, S., Correction (of pp. 618-626, vol. 95, no. 9), Mon. Weather Rev., 96, 63-74, 1968.

Leetmaa, A., The response of the Somali Current to the southwest monsoon of 1970, Deep Sea Res., 19, 319-325, 1972.

Leetmaa, A., The response of the Somali Current at $2^{\circ} \mathrm{S}$ to the southwest monsoon of 1971, Deep Sea Res., 20, 355-374, 1973.

Swallow, J. C., and J. G. Bruce, Current measurements off the Somali Coast during the southwest monsoon of 1964, Deep Sea Res., 13(5), 861-888, 1966.

Warren, B. A., H. Stommel, and J. C. Swallow, Water masses and patterns of flow in the Somali Basin during the southwest monsoon of 1964, Deep Sea Res., 13, 825-860, 1966.

(Received December 26, 1979; revised May 9, 1980; accepted May 13, 1980.) 
MANDATORY DISTRIBUTION LIST

FOR UNCLASSIFIED TECHNICAL REPORTS, REPRINTS, AND FINAL REPORTS

PUBLISHED BY OCEANOGRAPHIC CONTRACTORS

OF THE OCEAN SCIENCE AND TECHNOLOGY DIVISION

OF THE OFFICE OF NAVAL RESEARCH

(REVISED NOVEMBER 1978)

1 Deputy Under Secretary of Defense

(Research and Advanced Technology)

Military Assistant for Environmental Science

Room 30129

Washington, D.C. 20301

Office of Naval Research

800 North Quincy Street

Arlington, VA 22217

3 ATTN: Code 483

1 ATTN: Code 460

2 ATTN: 102B

1 CDR J. C. Harlett, (USN)

ONR Representative

Woods Hole Oceanographic Inst.

Woods Hole, MA 02543

Commanding Officer

Naval Research Laboratory

Washington, D.C. 20375

6 ATTN: Library, Code 2627
12 Defense Documentation Center Cameron Station

Alexandria, VA 22314

ATTN: DCA

Commander

Naval Oceanographic Office NSTL Station

Bay St. Louis, MS 39522

1 ATTN: Code 8100

1 ATTN: Code 6000

1 ATTN: Code 3300

1 NODC/NOAA

Code 0781

Wiscons in Avenue, N.W. Washington, D.C. 20235 
UNCLASSIFIED $\quad 7 / 81$

SECURITY CLASSIFICATION OF THIS PAGE (When Data Enterod)

\begin{tabular}{|c|c|}
\hline REPORT DOCUMENTATION PAGE & $\begin{array}{l}\text { READ INSTRUCTIONS } \\
\text { BEFORE COMPLETING FORM }\end{array}$ \\
\hline \begin{tabular}{l|l} 
1. REPORT NUMEER & 2. GOVT ACCESSION NO. \\
WHOI $-81-59$ &
\end{tabular} & 3. RECIPIENT'S CATALOG NUMBER \\
\hline 4. TITLE (end Subttite) & 5. TYPE OF REPORT A PERIOD COVERED \\
\hline \multirow{2}{*}{$\begin{array}{l}\text { SOMALI EDDY FORMATION DURING THE COMMENCEMENT OF } \\
\text { THE SOUTHWEST MONSOON, } 1978\end{array}$} & Technical \\
\hline & $\begin{array}{l}\text { 6. PERFORMING ORG. REPORT NUMBER } \\
\text { WHOI Cont. \#4496 }\end{array}$ \\
\hline $\begin{array}{l}\text { 7. AUTHOR(O) } \\
\text { J.G. Bruce, D.R. Quadfasel and J.C. Swallow }\end{array}$ & $\begin{array}{l}\text { 8. CONTRACT OR GRANT NUMBER(d) } \\
\text { * N00014-74-C-0262; NR } 083- \\
004 \\
* \text { N00014-79-C-0071; NR 083-00 }\end{array}$ \\
\hline \multirow{2}{*}{$\begin{array}{l}\text { 9. PEAFORMING ORGANIZATION NAME AND ADDRESS } \\
\text { Woods Hole Oceanographic Institution } \\
\text { Woods Hole, MA 02543 }\end{array}$} & $\begin{array}{l}\text { 10. PROGAAMELEMENT, PROJECT, TASK } \\
\text { * AREA \& WORK UNIT NUMERS TAST }\end{array}$ \\
\hline & NR $083-004$ \\
\hline \multirow{2}{*}{$\begin{array}{l}\text { 11. CONTROLLING OFFICE NAME AND ADDRESS } \\
\text { NORDA/National Space Technology Laboratory } \\
\text { Bay St. Louis, MS } 39529\end{array}$} & 12. REPORT DATE \\
\hline & \begin{tabular}{|l} 
July \\
13. NUMBER OF PAGES
\end{tabular} \\
\hline \multirow[t]{2}{*}{ 14. MONITORING AGENCY NAME \& ADDRESS(If difforent from Controlline Oflice) } & $\begin{array}{l}\text { 15. SECURITY CLASS. (of thit roport) } \\
\text { Unclassified }\end{array}$ \\
\hline & $\begin{array}{l}\text { 15.. DECLASSIFICATION/DOWNGRADING } \\
\text { SCHEDULEETH }\end{array}$ \\
\hline
\end{tabular}

Approved for public release; distribution unlimited.

17. DISTRIBUTION STATEMENT (of the abotract entered in Blook 20, 11 difforent from Ropopt)

18. SUPPLEMENTARY NOTES

Reprinted from: Journal of Geophysical Research 85 (C11): 6654-6660 (November 20, 1980).

19. KEY WOKDS (Continue on reverae olde $/$ neceesery end Identify by block number)

1. Somali current

2. Southwest monsoon

3. Eddies

20. ABSTRACT (Consinuo on rovorve aldo $1 /$ noceseary and ldentify by block number)

An early stage of the Somali eddy circulation was mapped in the period May 29 to June 13, 1978, using expendable bathythermograph data at closely spaced stations. By this time the SW monsoon had been blowing at $5^{\circ} \mathrm{N}$ for about 4 weeks and the large anticyclonic eddy in the northern Somali Basin was clearly discernible between $3^{\circ} \mathrm{N}$ an $10^{\circ} \mathrm{N}$. It is estimated that the offshore transport at this time was approximately half of that occurring during the period when the eddy reaches maximum size and strength during August and September. A smaller southern eddy was observed just offshore between the equator and $3^{\circ} \mathrm{N}$. 


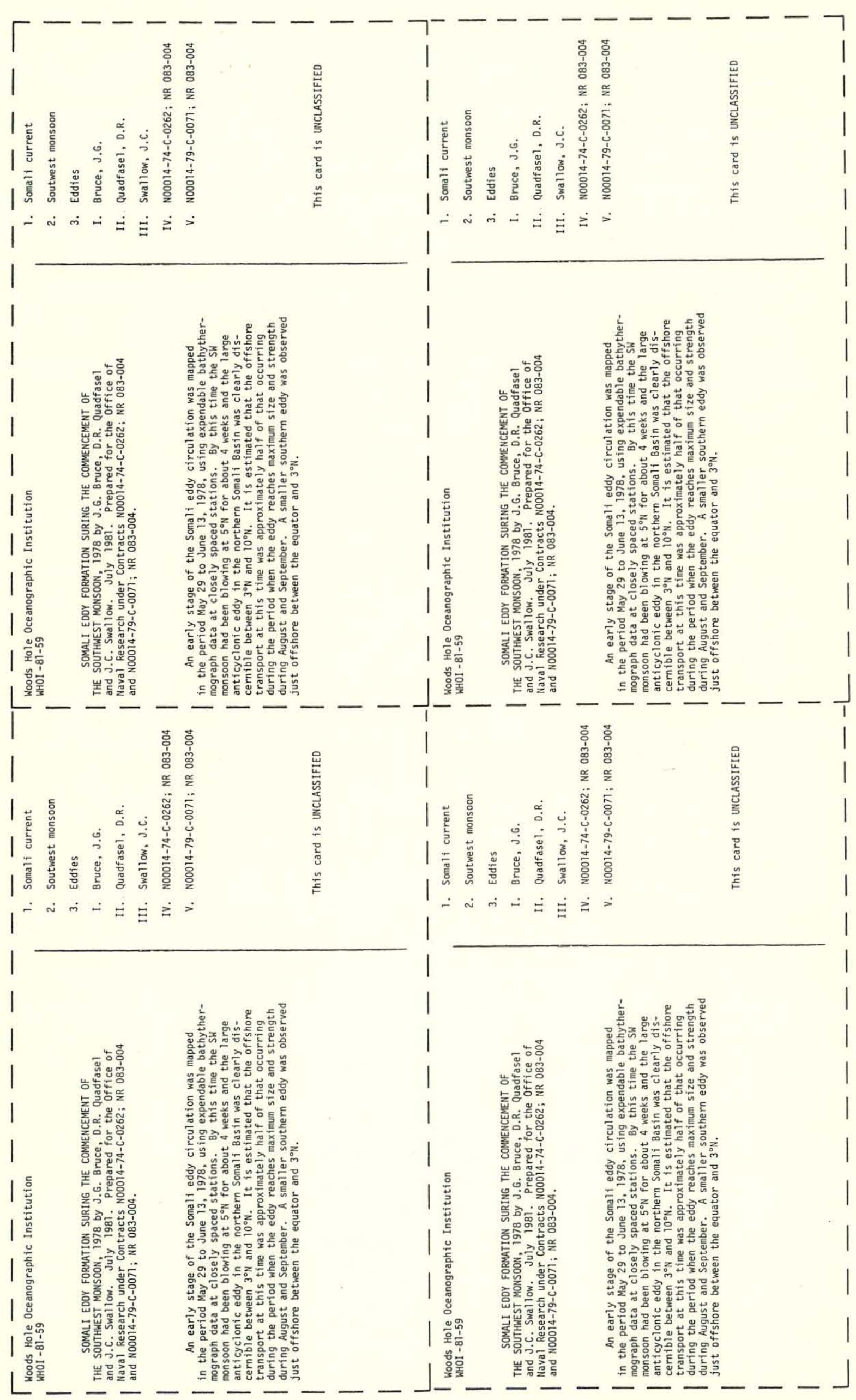

